\title{
EKSTRAKSI SELULOSA DARI SERBUK GERGAJI KAYU SENGON MELALUI PROSES DELIGNIFIKASI ALKALI ULTRASONIK
}

\author{
Prida Novarita Trisanti, Sena Setiawan H.P., Elysa Nura'ini dan Sumarno \\ Departemen Teknik Kimia - Institut Teknologi Sepuluh Nopember \\ Kampus ITS, Keputih, Sukolilo Surabaya, 60111 \\ E-mail: pridanova@chem-eng.its.ac.id
}

\begin{abstract}
ABSTRAK
EKSTRAKSI SELULOSA DARI SERBUK GERGAJI KAYU SENGON MELALUI PROSES DELIGNIFIKASI ALKALI ULTRASONIK. Kayu sengon (Albizia chinensis) merupakan salah satu jenis kayu yang melimpah di Indonesia. Kandungan selulosa pada kayu sengon cukup tinggi sebesar 41,17\%. Proses ekstraksi selulosa dari kayu sengon dapat dilakukan melalui proses delignifikasi atau penghilangan kandungan lignin. Umumnya, proses delignifikasi dilakukan dengan larutan alkali pada konsentrasi tinggi, suhu tinggi dan waktu yang lama. Agar konsentrasi alkali yang digunakan rendah dan waktu lebih pendek, proses delignifikasi dapat dilakukan dengan bantuan ultrasonik. Tujuan dari penelitian ini adalah mengetahui pengaruh kondisi operasi (suhu dan waktu) proses delignifikasi dengan ultrasonik terhadap kadar selulosa yang diperoleh. Proses delignifikasi dilakukan dengan mencampur serbuk kayu sengon (40 mesh) dengan larutan $\mathrm{NaOH}(0,3 \mathrm{M})$ dengan perbandingan 1:30 (w/v). Kondisi operasi yang digunakan adalah suhu $30^{\circ} \mathrm{C}$ dan $40{ }^{\circ} \mathrm{C}$ pada berbagai waktu (10 menit hingga 70 menit). Setelah proses delignifikasi, produk di-bleaching dengan $\mathrm{NaOCl}$ hingga warnanya menjadi putih. Analisis yang dilakukan antara lain adalah metode Chesson, X-Ray Diffraction (XRD) dan Scanning Electron Microscopy (SEM). Hasil dari analisa menunjukkan bahwa kristalinitas tertinggi diperoleh sebesar $77,05 \%$ pada $40{ }^{\circ} \mathrm{C}$ selama 30 menit dan kadar lignin turun hingga mencapai $0,41 \%$.
\end{abstract}

Kata kunci: Kayu sengon, Delignifikasi, Alkali, Ultrasonik, Selulosa

\begin{abstract}
SELULOSE EXSTRACTION FROM SAW DUST OF SENGON WOOD USING BY PROCESS OF DELIGNIFITION OF ULTRASOUND ALKALINE. Sengon wood (Albizia chinensis) is one type of wood that is abundant in Indonesia. Cellulose content in sengon wood is quite high, up to $41.17 \%$. The process of cellulose extraction from sengon wood can be done through the process of delignification or removal of lignin content. Generally the delignification process is carried out with an alkaline solution at high concentration, high temperature and long time. In order to use lower alkaline concentration and shorter time process, the delignification process can be performed by assisted ultrasound. The purpose of this research is to study the effect of operating conditions (such as temperature and time) of ultrasonic delignification process on cellulose content in the cellulose product. The delignification process was carried out by mixing the sengon wood ( 40 mesh) with $\mathrm{NaOH}$ solution $(0.3 \mathrm{M})$ at a ratio of $1: 30(\mathrm{w} / \mathrm{v})$. The operating conditions used are $30{ }^{\circ} \mathrm{C}$ and $40{ }^{\circ} \mathrm{C}$ at various times (10-70 minutes). After the delignification process, the product is bleached with $\mathrm{NaOCl}$ until the color of product becomes white. The product was analyzed by Chesson method, XRD (X-Ray Diffraction), and SEM (Scanning Electron Microscopy). The results of the analysis showed that the highest crystallinity was $77.05 \%$ at $40^{\circ} \mathrm{C}$ for 30 minutes and lignin content was decreased until $0.41 \%$.
\end{abstract}

Keywords: Sengon wood, Delignification, Alkaline, Ultrasonic, Cellulose 


\section{PENDAHULUAN}

Kayu sengon (Albizia chinensis) merupakan salah satu jenis kayu yang jumlahnya cukup melimpah di Indonesia. Berdasarkan data pada tahun 2015, produksi kayu sengon di Indonesia mencapai 2,58 juta $\mathrm{m}^{3}$ [1]. Hal ini karena kayu ini termasuk jenis tanaman cepat tumbuh yang paling banyak sehingga banyak dibudidayakan oleh masyarakat, khususnya di Jawa [2]. Kayu sengon banyak digunakan pada pembangunan perumahan (konstruksi), pembuatan peti, pulp dan korek api. Sehingga jika penggunaan kayu sengon tinggi, maka akan dihasilkan juga limbah kayu yang tinggi pula, terutama limbah serbuk gergajinya.

Sekarang limbah serbuk gergaji kayu sengon hanya dimanfaatkan sebagai media tanam jamur putih bahan pembuatan briket dan bahan pembuatan papan partikel [3-5]. Padahal limbah serbuk kayu sengon ini masih dapat dimanfaatkan sehingga menghasilkan produk dengan nilai jual yang lebih tinggi. Salah satunya adalah dengan ekstraksi selulosa yang ada didalam kayu sengon. Hal ini karena selulosa yang terkandung dalam serbuk kayu sengon cukup tinggi yakni sekitar $45,42 \%$, dan sisanya adalah hemiselulosa $(21 \%)$, lignin $(26,50 \%)$ dan abu $(7,08 \%)[6]$

Selulosa, $\left(\mathrm{C}_{6} \mathrm{H}_{10} \mathrm{O}_{5}\right) \mathrm{n}$, komponen utama yang ada pada hampir semua sel tumbuhan. Selulosa terdiri dari rantai panjang polimer yang terbentuk dari monomer glukosa [7]. Selulosa dapat digunakan di berbagai industri, antara lain adalah pada pembuatan kertas, industri tekstil, packaging, dan produk turunannya, seperti glukosa, selulosa asetat, alkohol dan lainnya [8]. Dalam lignoselulosa, selulosa terjebak didalam matrik lignin dan hemiselulosa. Sehingga perlu diperoleh suatu metode untuk mengekstraksi selulosa tersebut didalam lignoselulosa tersebut.

Proses ekstraksi selulosa dari kayu dapat dilakukan melalui proses delignifikasi. Proses delignifikasi adalah proses kimia untu memisahkan lignin dan hemiselulosa dari selulosa [9]. Metode-metode delignifikasi antara lain adalah perlakuan dengan alkali, perlakuan dengan asam, biodelignifikasi, dan organosolv [10]. Metode yang umum digunakan perlakuan alkali, seperti pada pembuatan pulp. Hal ini karena pada perlakuan alkali bekerja pada suhu dan tekanan rendah, dan biaya operasi yang rendah. Selama perlakuan dengan alkali, ikatan ester yang berikatan silang dengan lignin dan hemiselulosa terdegradasi [11]. Selain itu juga ikatan glikosidik yang ada didalam lignoselulosa rusak yang mengakibatkan adanya perubahan pada struktur lignin menjadi suatu polimer yang seperti lignin [12]. Jenis alkali yang dapat digunakan antara lain adalah kalsium hidroksida $\left(\mathrm{CaOH}_{2}\right)$, natrium hidroksida $(\mathrm{NaOH})$, amoniak $\left(\mathrm{NH}_{4} \mathrm{OH}\right)$, dan lainnya [13]. Perlakuan alkali dengan $\mathrm{NaOH}$ merupakan salah satu metode yang paling efisien untuk melarutkan komponen selain selulosa [12]. Hal ini dikarenakan $\mathrm{NaOH}$ merupakan alkali kuat yang memiliki kelarutan yang tinggi dengan air dan dapat bereaksi pada suhu rendah [14].

Proses ekstraksi selulosa yang dilakukan pada penelitian ini adalah dengan menggabungkan proses ekstraksi menggunakan alkali dengan ultrasonik. Hal ini karena ultrasonik dapat menghasilkan efek sonokimia dan mechano acoustic karena fenomena kavitasinya, yang mana terjadi perbedaan tekanan dalam larutannya. Efek mechano acoustic dapat meningkatkan mikrojet dari bubble collapse yang dihasilkan sehingga terjadi gangguan pada dinding sel dari lignoselulosa. Fenomena sonokimia dapat menghasilkan radikal bebas yang menyebabkan reaksi oksidasi menjadi lebih cepat pada suhu rendah dan juga serangan kimia pada komponen lignoselulosa [10]. Efisiensi proses ekstraksi dapat meningkat dikarenakan meningkatnya penghilangan lignin dan konsentrasi larutan alkali yang digunakan dapat diperkecil [15]. Sehingga pengoptimalan proses ekstraksi selulosa dapat dilakukan dengan mengkombinasi metode alkali dengan ultrasonik.

Tujuan dari penelitian ini adalah mengetahui pengaruh kondisi operasi (suhu dan waktu) proses delignifikasi alkali dengan bantuan ultrasonik terhadap kadar selulosa yang diperoleh.

\section{METODE PERCOBAAN}

\section{Bahan dan Alat}

Bahan baku yang digunakan adalah serbuk gergaji kayu sengon yang diperoleh dari Desa Kendal, Magetan, Jawa Timur. Natrium hidroksida (Merck), $\mathrm{NaOH}$ (Merck), dan sebagai agent pemutih adalah natrium hipoklorit dan $\mathrm{NaOCl}$ (SAP).

Penelitian ini dilakukan di Laboratorium Teknologi Material, Departemen Teknik Kimia, FTI-ITS. Peralatan yang digunakan antara lain adalah ultrasonik tanduk (Sonics, 500 Watt Ultrasonic Processor model VC 505), indikator suhu (Shimaden, SR 1), termokopel (Tipe K, $1 /$ 16 in, AS One), kondensor, pengaduk (Stirrer SS3, Stuart Scientific), beaker glass, corong pemisah dan oven (VWR Scientific model 1670).

\section{Cara Kerja}

Serbuk gergaji kayu sengon diolah secara mekanik hingga berbentuk bubuk berukuran 40 mesh. Serbuk kayu dimasak dalam akuades dengan suhu $100{ }^{\circ} \mathrm{C}$ selama 1 jam untuk menghilangkan pengotor yang ada didalamnya. Serbuk tersebut dikeringkan dalam oven pada suhu $45^{\circ} \mathrm{C}$ selama 24 jam. Proses ekstraksi selulosa dilakukan dengan larutan $\mathrm{NaOH}(0,5 \mathrm{M})$ dibantu dengan ultrasonik tanduk. Perbandingan serbuk gergaji kayu sengon dan larutan $\mathrm{NaOH}$ sebesar 1:30 (w/v). Proses delignifikasi ultrasonik dilakukan pada suhu $30{ }^{\circ} \mathrm{C}$ dan $40{ }^{\circ} \mathrm{C}$ selama berbagai waktu ( 30 menit hingga 90 menit). 
Produk delignifikasi dipisahkan antara padatan dan cair dengan menggunakan kertas saring. Produk padatan dibleaching menggunakan $\mathrm{NaOCl} 5 \%$ pada suhu $50{ }^{\circ} \mathrm{C}$ hingga warna padatan menjadi putih. Padatan dicuci menggunakan aquadest hingga $\mathrm{pH}$ netral ( $\mathrm{pH} 7)$. Setelah itu dikeringkan dalam oven pada suhu $\pm 45^{\circ} \mathrm{C}$ selama 24 jam.

\section{Karakterisasi}

\section{Metode Chesson Datta}

Untuk mengetahui kadar selulosa, lignin dan selulosa dilakukan analisis dengan menggunaakan metode Chesson-Datta [16]. 1 gram sampel kering (berat a) dicampur dengan aquadest $(150 \mathrm{~mL})$ dan dipanaskan pada temperatur $100{ }^{\circ} \mathrm{C}$ selama 1 jam. Kemudian campuran disaring dan dicuci dengan aquadest panas. Padatan dikeringkan dalam oven hingga beratnya konstan (berat b). Kemudian padatan dicampurkan dengan $150 \mathrm{~mL} \mathrm{H}_{2} \mathrm{SO}_{4}(1 \mathrm{~N})$ dan dipanaskan pada suhu $100{ }^{\circ} \mathrm{C}$ selama $1 \mathrm{jam}$. Padatan disaring dan dicuci dengan akuades. Setelah itu padatan dikeringkan (berat c). Padatan yang sudah kering tersebut direndam dalam $10 \mathrm{~mL} \mathrm{H}_{2} \mathrm{SO}_{4}(72 \%)$ pada suhu ruang selama 4 jam. Setelah itu, $150 \mathrm{~mL} \mathrm{H}_{2} \mathrm{SO}_{4}(1 \mathrm{~N})$ ditambahkan dalam campuran dan direfluks selama 1 jam. Kemudian padatan dicuci dengan $400 \mathrm{~mL}$ aquadest dan dipanaskan pada suhu $105{ }^{\circ} \mathrm{C}$ dalam oven. Pemanasan dilakukan hingga beratnya konstan (berat d). Setelah itu padatan dipanaskan hingga menjadi abu dan ditimbang beratnya (berat e). Persentase selulosa dan lignin dapat dihitungan dengan Persamaan (1) dan Persamaan (2).

$$
\begin{aligned}
& \% \text { selulosa }=\frac{(\mathbf{d}-\mathbf{c})}{\mathbf{a}} \times 100 \% \\
& \% \text { lignin }=\frac{(\mathbf{e}-\mathbf{d})}{\mathbf{a}} \times 100 \%
\end{aligned}
$$

\section{Analisis X-Ray Diffraction (XRD)}

Pengujian $X R D$ dilakukan dengan menggunakan PANalytical PW 3373/00 X'Pert X-Ray Diffractometer (Belanda). Radiasi CuK $\alpha$ pada bilangan gelombang $1,54 \AA$ dengan voltase $40 \mathrm{kV}$ and $30 \mathrm{~mA}$. Intensitas relatif direkam pada $2 \theta$ dari $5^{\circ}$ hingga $50^{\circ}$. Perhitungan derajat kristalinitas dilakukan menggunakan Persamaan (3) [17].

$$
\mathbf{C r I}=\frac{\left(\mathbf{I}_{002}-\mathbf{I}_{\mathrm{AM}}\right)}{\mathbf{I}_{002}}
$$

Dimana :

$$
\begin{aligned}
\mathrm{CrI}= & \text { Derajat kristalitinas } \\
\mathrm{I}_{002}= & \begin{array}{l}
\text { Intensitas dari bagian kristalin } \\
\left(\text { pada } 2 \theta=22^{\circ} \text { hingga } 23^{\circ}\right)
\end{array} \\
\mathrm{I}_{\mathrm{AM}}= & \begin{array}{l}
\text { Intensitas dari bagian amorf } \\
\left(\text { pada } 2 \theta=18^{\circ} \text { hingga } 19^{\circ}\right)
\end{array}
\end{aligned}
$$

\section{Analisis Scanning Electron Microscope}

Morfologi dari material untuk setiap proses diamati dengan menggunakan Scanning Electron Microscopy (EVO MA 10, Carl Zeiss, Jerman). Sampel dilapisi dengan emas menggunakan sputter coater (Emitech, Dubai).

\section{HASIL DAN PEMBAHASAN}

Pada penelitian ini, proses ekstraksi selulosa dilakukan dengan metode alkali dibantu dengan ultrasonik. Kondisi operasi yang dilakukan adalah pada temperatur $30^{\circ} \mathrm{C}$ dan $40^{\circ} \mathrm{C}$ dan berbagai waktu ekstraksi (30 menit hingga 90 menit). Setelah dilakukan proses ekstraksi, perubahan warna terjadi baik pada warna larutan dan juga padatannya. Secara visual, perubahan warna tersebut dapat dilihat pada Gambar (1).
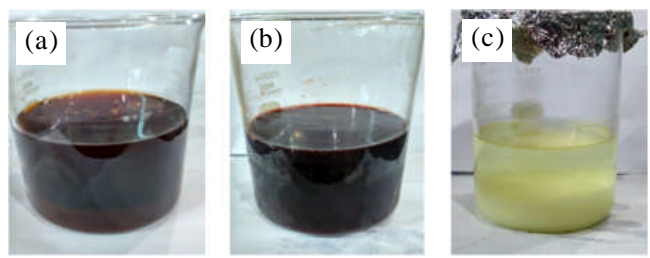

Gambar 1. Campuran serbuk kayu dan larutan $\mathrm{NaOH}$ (a). sebelum proses, (b). setelah proses delignifikasi alkali ultrasonik dan (c). setelah proses bleaching.

Gambar 1 menunjukkan terjadinya perubahan pada campuran serbuk kayu sengon dan larutan $\mathrm{NaOH}$ pada berbagai proses. Gambar 1(a) merupakan hasil pencampuran antara serbuk kayu dan larutan $\mathrm{NaOH}$ saja. Larutan $\mathrm{NaOH}$ mengalami perubahan warna menjadi coklat seperti warna serbuk kayu. Setelah dilakukan proses delignifikasi dengan ultrasonik, campuran mengalami perubahan warna menjadi hitam pekat seperti yang ditunjukkan pada Gambar 1(b). Larutan $\mathrm{NaOH}$ dapat digunakan dalam proses delignifikasi karena larutan tersebut dapat merusak ikatan eter yang menghubungkan antara lignin dengan selulosa, menghilangkan lignin dan meningkatkan porositas dari biomassa $[18,19]$. Pemecahan ikatan eter tersebut dapat dilihat pada Gambar (2).
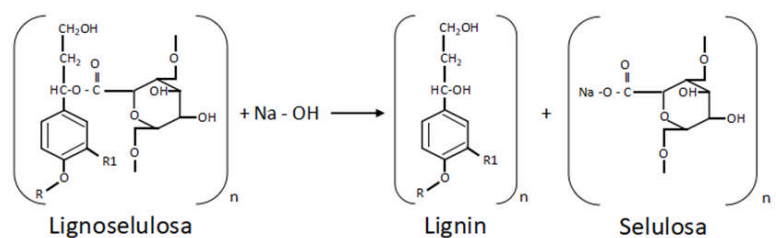

Gambar 2. Mekanisme reaksi lignoselulosa dengan $\mathrm{NaOH}$ [27].

Setelah proses delignifikasi, produk padatannya di-bleaching dengan menggunakan larutan $\mathrm{NaOCl}$ (5\%). $\mathrm{NaOCl}$ merupakan salah satu agent bleaching yang umum digunakan pada proses pembuatan kertas [20]. Proses bleaching bertujuan untuk memperbaiki 
brightness, memperbaiki kemurnian, dan meminimalisir terjadinya degradasi serat selulosa [21]. Pada proses ini terjadi degradasi dari rantai lignin yang tersisa. Hal ini dikarenakan adanya ion hipoklorit yang merupakan active bleaching agent. Reaksi yang terjadi diperlihatkan pada Persamaan (4).

$$
\begin{array}{ll}
\mathrm{NaOCl}+\mathrm{H}_{2} \mathrm{O} & \longrightarrow \mathrm{NaOH}+\mathrm{HOCl} \\
\mathrm{HOCl} & \longrightarrow \mathrm{H}^{+}+\mathrm{OCl} \\
\mathrm{HOCL}+\mathrm{H}^{+}+\mathrm{Cl}^{-} \longrightarrow \mathrm{Cl}_{2}+\mathrm{H}_{2} \mathrm{O}
\end{array}
$$

Reaksi ini menyebabkan perubahan warna selulosa dari coklat menjadi putih. Seperti yang terlihat pada Gambar 1(c), dimana terlihat bahwa warna padatan dan larutan menjadi lebih terang [22].

Pembuktian adanya proses degradasi lignin pada proses delignifikasi alkali-ultrasonik dapat dilihat dari penurunan kadar lignin yang ada pada produk. Penurunan kadar tersebut dapat diketahui dari hasil analisis Chesson Datta. Analisis ini diperoleh kadar selulosa, hemiselulosa dan lignin baik sebelum dan setelah proses [23]. Hasil analisis Chesson Datta ditampilkan pada Tabel 1 .

Tabel 1. Hasil perhitungan kadar selulosa, hemiselulosa dan lignin.

\begin{tabular}{lrrr}
\hline \multirow{2}{*}{ Komponen (\%) } & $\begin{array}{c}\text { Kayu sengon } \\
\text { (native) }\end{array}$ & \multicolumn{2}{c}{ Produk delignifikasi } \\
\cline { 3 - 4 } & $410^{\circ} \mathrm{C} ;$ & $40^{\circ} \mathrm{C} ;$ \\
Selulosa & 41,1 & 75,3 & 30 menit \\
Hemiselulosa & 22,26 & 10,38 & 77,96 \\
Lignin & 17,51 & 2,58 & 0,14 \\
Abu & 19,13 & 11,74 & 0,93 \\
\hline
\end{tabular}

Berdasarkan Tabel 1, serbuk kayu sengon sebelum proses mengandung selulosa yang cukup tinggi yakni sebesar $41,17 \%$. Setelah dilakukan proses, kadar selulosa meningkat hingga mencapai $75,3 \%\left(30{ }^{\circ} \mathrm{C}\right.$, 30 menit) dan 77,96\% (40 ${ }^{\circ} \mathrm{C}, 30$ menit). Peningkatan kadar selulosa terjadi dikarenakan menurunnya kadar lignin dan hemiselulosa pada produk akibat proses delignifikasi. Penggunaan $\mathrm{NaOH}$ pada proses ini dapat menyebabkan larutnya lignin dan hemiselulosa yang ditunjukkan dengan adanya penurunan kadar keduanya pada produk [7]. Kadar selulosa yang diperoleh pada penelitian ini lebih tinggi bila dibandingkan dengan metode alkali. Delignifikasi terhadap serat Agave americana $L$ dengan menggunakan larutan $\mathrm{NaOH}$ (20\%) pada suhu $30^{\circ} \mathrm{C}$ selama 1 jam, diperoleh kadar selulosa 73,90 \% [20]. Perbedaan kadar selulosa yang diperoleh ini menunjukkan bahwa dengan adanya bantuan ultrasonik, proses delignifikasi dapat berjalan dengan baik meskipun dengan menggunakan suhu rendah, konsentrasi alkali rendah dan waktu delignifikasi yang singkat [15].

Selulosa memiliki struktur kristal yang berlawanan dengan hemiselulosa dan lignin yang merupakan material amorf. Untuk mengetahui derajat kristalinitas dari produk selulosa yang dihasilkan dapat diperoleh dengan analisis $X R D$ [23]. Difraktogram $X R D$ untuk serbuk kayu sengon sebelum proses dan setelah proses dapat dilihat pada Gambar (2).

Gambar 3 menunjukkan bahwa seluruh difraktogram memiliki puncak tajam pada $2 \theta$ sekitar $18^{\circ}$ dan $23^{\circ}$, yang mana pada kedua puncak tersebut menunjukkan jenis selulosa tipe I [25]. Hal ini mengindikasikan bahwa struktur kristal dari selulosa tidak berubah selama proses alkali dan ultrasonik. Setelah proses delignifikasi, hanya terjadi perubahan pada besaran intensitas.

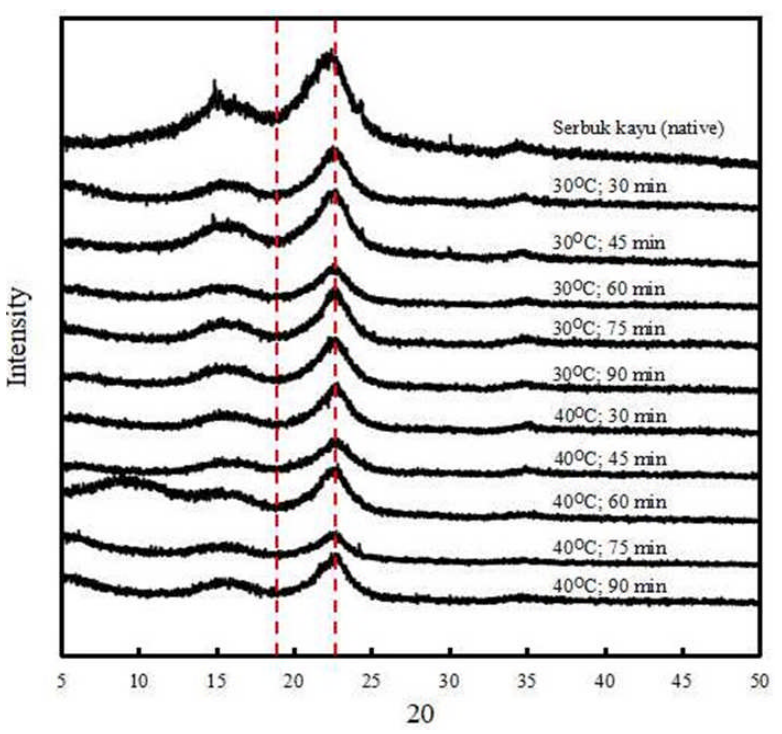

Gambar 3. Profil $X R D$ untuk kayu sengon tanpa proses dan produk delignifikasi $\left(30^{\circ} \mathrm{C}\right.$ dan $\left.40^{\circ} \mathrm{C}\right)$.

Dari difraktogram $X R D$, derajat kristalinitas dapat dihitung dengan metode Segal [17]. Hasil perhitungan derajat kristalinitas dapat dilihat pada Tabel 2.

\begin{tabular}{|c|c|c|}
\hline \multicolumn{2}{|c|}{ Sampel } & Derajat Kristalitinas (\%) \\
\hline \multicolumn{2}{|c|}{ Kayu sengon (native) } & 56.43 \\
\hline \multicolumn{3}{|c|}{ Produk delignifikasi : } \\
\hline \multirow[t]{5}{*}{$-\quad 30{ }^{\circ} \mathrm{C}$} & 30 menit & 73.26 \\
\hline & 45 menit & 68.87 \\
\hline & 60 menit & 74.40 \\
\hline & 75 menit & 75.79 \\
\hline & 90 menit & 72.46 \\
\hline \multirow[t]{5}{*}{$-40{ }^{\circ} \mathrm{C}$} & 30 menit & 77.05 \\
\hline & 45 menit & 73.11 \\
\hline & 60 menit & 72.76 \\
\hline & 75 menit & 67.20 \\
\hline & 90 menit & 72.99 \\
\hline
\end{tabular}

Table 2. Hasil perhitungan derajat kristalinitas pada berbagai suhu dan waktu delignifikasi.

Dari analisis $X R D$ dapat diketahui bahwa derajat kristalinitas untuk serbuk kayu sengon sebelum proses sebesar 56,43\%. Setelah proses delignifikasi alkali ultrasonik terjadi kenaikan derajat kristalinitas dari produk. Hal ini dikarenakan lignin yang merupakan komponen amorf dapat dihilangkan sehingga hanya 
tersisa komponen kristalin (selulosa) dalam produk [15]. Dari Gambar 3, terlihat bahwa pada suhu $30{ }^{\circ} \mathrm{C}$ dengan semakin lamanya waktu, derajat kristalinitas dari produk cenderung mengalami peningkatan. Derajat kristanilitas tertinggi dicapai pada 75 menit, yakni sebesar 75,79\%.

Namun hal ini tidak terjadi pada suhu yang lebih tinggi $\left(40^{\circ} \mathrm{C}\right)$. Pada suhu $40^{\circ} \mathrm{C}$, semakin lama proses delignifikasi maka derajat kristalinitas dari selulosa cenderung mengalami penurunan. Derajat kristalinitas tertinggi dicapai pada waktu terpendek yakni 30 menit sebesar 77,09\%. Penurunan kristalinitas tersebut dimungkinkan akibat adanya radikal $\mathrm{H}^{*}$ yang terbentuk dari disosiasi air pada proses ultrasonik. Radikal $\mathrm{H}^{*}$ sangat reaktif karena memiliki elektron tunggal yang tidak berpasangan. Hal ini mengakibatkan radikal $\mathrm{H}^{*}$ menyerang sebagian daerah kristal dan amorp pada selulosa, sehingga kristalinitasnya menjadi menurun [25]. Pada proses ultrasonik juga menimbulkan terjadinya fenomena hot spot yang ditimbulkan saat runtuhnya kavitasi. Pecahnya gelembung gas menyebabkan terbentuknya micro bubble jet. Micro bubble jet tersebut menyerang bagian terluar dari lignoselulosa yaitu lignin. Dengan semakin lamanya waktu delignifikasi, maka semakin banyak bagian lignin yang terserang micro-bubble jet yang menyebabkan lignin terkelupas dan terlarut. Ketika sebagian besar
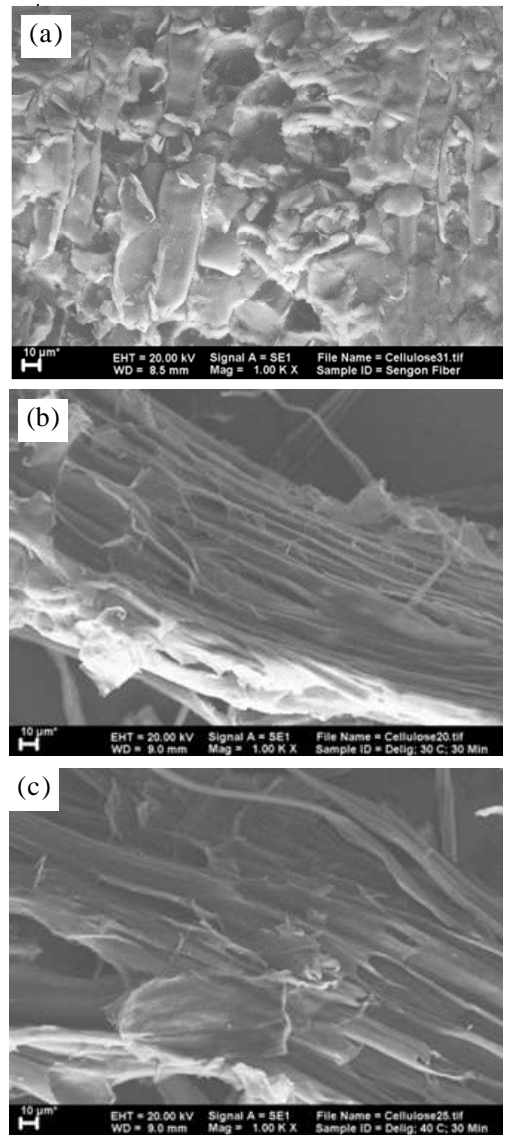

Gambar 4. (a). Morfologi dari (a) serbuk kayu sengon sebelum proses delignifikasi, produk delignifikasi-sonikasi pada: (b) suhu $30^{\circ} \mathrm{C}$ dan (c) suhu $40^{\circ} \mathrm{C}$ selama 30 menit. lapisan lignin larut dalam larutan $\mathrm{NaOH}$, maka micro bubble jet menyerang bagian selulosa dan hemiselulosa. Hemiselulosa menjadi larut sebagian dan selulosa terkoyak. Terkoyaknya selulosa tersebut menyebabkan kristalinitas menjadi turun [27].

Perubahan morfologi dan permukaan dari produk setelah proses dapat dilihat pada hasil pengukuran SEM (Gambar 4).

Morfologi permukaan dari serbuk kayu sengon sebelum proses dapat dilihat pada Gambar 4(a). Terlihat bahwa memiliki permukaan yang halus dan rapat. Setelah dilakukan proses delignifikasi alkali ultrasonik, serbuk kayu terkoyak dan hancur yang menyebabkan permukaannya menjadi kasar dan berongga. Seperti yang terlihat pada Gambar 4(b) dan Gambar 4(c). Hal ini menunjukkan bahwa dengan kombinasi proses delignifikasi alkali dan ultrasonik dapat menghancurkan dan menghilangkan permukaan luar dan membuka bagian dalam dari fiber [27]. Selain itu juga dapat menyebabkan terjadinya retakan akibat adanya erosi. Erosi (attiration) ini muncul akibat adanya efek fisik dari gelombang akustik dan micro turbulance yang dihasilkan oleh gelembung kavitasi [12].

\section{KESIMPULAN}

Proses ekstraksi selulosa dari serbuk gergaji kayu sengon dapat dilakukan melalui proses delignifikasi alkali disertai ultrasonik. Kandungan selulosa meningkat setelah dilakukan proses delignifikasi alkali disertai ultrasonik, yakni dari $41,17 \%$ menjadi $75,3 \%\left(30^{\circ} \mathrm{C}\right.$, 30 menit) dan $77,96 \%$ ( $40{ }^{\circ} \mathrm{C}, 30$ menit). Dan derajat kristalinitas tertinggi dicapai pada suhu $40{ }^{\circ} \mathrm{C}$ selama 30 menit yaitu $77,05 \%$.

\section{UCAPAN TERIMAKASIH}

Ucapan terimakasih penulis sampaikan atas pemberian dana penelitian dari LPPM ITSKemeristekdikti melalui Penelitian Pemula sesuai dengan Surat Perjanjian Penelitian Nomor : 695/PKS/ITS/2017.

\section{DAFTAR ACUAN}

[1]. Badan Pusat Statistik. Statistika Produksi Kehutanan 2015, BPS-Statistics Indonesia. Tersedia: https://www.bps.go.id/publication/2016, pp. 33-42, 2016.

[2]. Baskorowati, L. "Budidaya Sengon Unggul (Falcataria moluccana) Untuk Pengembangan Hutan Rakyat. Bogor: IPB Press, pp. 1-2, 2014.

[3]. Anggoro, D. D., Dzikri, M., Hanif, W. dan Fathoni, M. Z. "Pembuatan Briket Arang Dari Campuran Tempurung Kelapa dan Serbuk Gergaji Kayu Sengon." Jurnal Ilmiah Bidang Ilmu Kerekayasaan, vol. 38, no. 2, pp. 76-80, 2017. 
[4]. Sushardi dan E. Setyagama. "Pemanfaatan Limbah Plastik dan Serbuk Gergaji Sengon untuk Pembuatan Papan Komposit." in Proc. The 2nd University Research Coloquium, pp. 30-35, 2015.

[5]. A. Syafiih, Achmad dan E. N. Herliyana. "Perbandingan Faktor Media dari Campuran Serbuk Gergaji Sengon, Jabon dan Limbah Substrat Jamur Tiram pada Pertumbuhan Miselia Jamur Tiram (Pleurotus Spp.)." Jurnal Silvikultur Tropika, vol. 4, no. 3, pp. 196-200, 2013.

[6]. S. Hartati, E. Sudarmonowati, W. Fatriasari, Hermiati, E., Dwianto, W., Kaida, R., Baba, K., and Hayashi, T. "Wood Characteristic of Superior Sengon Collection and Prospect of Wood Properties Improvement through Genetic Engineering." J of Ind Wood Research Journal, vol. 1, no. 2, pp 103-106, 2010.

[7]. S. Harun and S. K. Geok. "Effect of Sodium Hydroxide Pretreatment on Rice Straw Composition." Indian Journal of Science and Technology, vol. 9, Issue. 21, 2016.

[8]. H. P. S. Khalil, Y. Davoudpour, Islam, M. N., Mustapha, A., Sudesh, K., Dungania, and R., Jawaid, M., "Production and Modification of Nanofibrillated Cellulose using Various Mechanical Processes: A Review", Carbohydrate Polymers, vol. 99, pp. 649-665, 2014.

[9]. R.C. Sun and J. Tomkinson. "Comparative Study of Lignin Isolated by Alkali and Ultrasound Assisted Alkali Extractions from Wheat Straw." Ultrasonics Sonochemistry, vol. 9, Issue 2, pp.85-93, 2002.

[10]. M.J. Bussermaker dan D. Zhang. "Effect of Ultrasound on Lignocellulosic Biomass as a Pretreatment for Biorefinery and Biofuel Applications." Industrial \& Engineering Chemistry Research. vol. 52. pp. 3563-3580, 2013.

[11]. Y. Sun and J. Cheng. "Hydvrolysis of Lignoselulosic Materials for Ethanol Production: A Review." Bioresource Technology, vol. 83, Issue 1, pp. 1-11, 2002.

[12]. S. Singh, S. T. P. Bharadwaja, P. K. Yadav, Vijayanand, S. Moholkar and A.Goyal. "Mechanistic Investigation in UltrasoundAssisted (Alkaline) Delignification of Parthenium Hysterophorus Biomass." Industrial and Engineering Chemistry Research, vol. 53, Issue 37, pp. 14241-14252. 2014.

[13]. K.Jaisamut, L. Paulova, P.Patakova, M. Rychtera, K. Melzoh ".Optimization of Alkali Pretreatment of Wheat Straw to be Used as Substrate for Biofuels Production.”,Plant Soil Environ. vol. 59, no. 12, pp. 537-542. 2013.

[14]. M. Lawther, R. Sun and W. B. Banks. "Effects of Extraction Conditions and Alkali Type on Yield and Composition of Wheat Straw Hemicellulose."
Journal of Applied Polymer Science, vol. 60, Issue 11, pp. 1827-1837, 1996.

15]. P. B. Subhedar and P. R. Gogate. "Alkaline and Ultrasound Assisted Alkaline Pretreatment for Intensification of Delignification Process from Sustainable Raw-Material." Ultrasonics Sonochemistry, vol. 21, Issue 1, pp. 216-225, 2014.

[16]. Mahyati, A. R. Patong, M. N. Djide, and P. Taba. "Biodegradation Of Lignin From Corn Cob By Using A Mixture Of Phanerochaete Chrysosporium, Lentinus Edodes And Pleurotus Ostreatus." International Journal of Scientific \& Technology Research, vol. 2, Issue 11, pp. 79-82, 2013.

17]. P. Khawas and S. C. Deka. "Isolation and Characterization of Cellulose Nanofibers from Culinary Banana Peel using High-Intensity Ultrasonication Combined with Chemical Treatment." Carbohydrate Polymers, vol. 137, pp. 608-616, 2016.

[18]. Kang, K.E., Jeong, G. T. and Park, D.H. "Pretreatment of Rapeseed Straw by Sodium Hydroxide." Bioprocess and Biosystems Eng, vol. 35, Issue 5, pp. 705-713, 2012.

[19]. Wang, M., Zhou, D., Wang, Y., Wei, S, Yang, W., Kuang, M., Lei, M, Fang, D., Xu, S., Du, S. "Bioethanol Production from Cotton Stalk: A Comparative Study of Various Pretreatments." Fuel, vol. 184, pp. 527-532, 2016.

[20]. A. E. O. B. Sghaier, Y. Chaabouni, , S. Msahli, and F.Sakli. "Morphological and Crystalline Characterization of $\mathrm{NaOH}$ and $\mathrm{NaOCl}$ Treated Agave Mericana L. Fiber". Industrial Crops and Products. vol. 36, Issue 1, pp. 257-266. 2012.

[21] F Khan and S.R Ahmad. "Chemical Modification and Spectroscopic Analysis of Jute Fibre." Polymer Degradation Stability, vol. 52, Issue 3, pp. 335-340, 1996.

[22]. G. Saharman, T.R. Christopher, R. Nima, W.Basuki, S. Nattakan, B. Emiliano and P. Ton.'Investigation into The Structural, Morphological, Mechanical and Thermal, Behaviour of Bacterial Cellulose after a Two-Step Purification Process." Bioresource Technology, Vol. 102, Issue 19, pp. 9105-9110, 2011.

[23] R. Datta. "Acidogenic Fermentation of Lignocellulose-Acid Yield And Conversion of Components." Biotechnology and Bioengineering, vol. 23, Issue 9, pp. 2167-2170, 1981.

[24]. N. Johar, I .Ahmad and A. Dufresne. "Extraction, Preparation and Characterization of Cellulose Fibres and Nanocrystals from Rice Husk." Industrial Crops and Products, vol. 37, Issue 1, pp. 93-99, 2012.

[25]. Y. Nishiyama, J. Sugiyama, H. Chanzy and P. Langan. "Crystal Structure and Hydrogen Bonding System in Cellulose IQ from Synchrotron X-ray and Neutron Fiber Diffraction." Journal of the 
American Chemical Society, Vol. 125, Issue 47, pp. 14300-14306, Nov. 2003

[26. Chatel, G., D. O. Vigier, K, Jérôme, F. "Sonochemistry: What Potential for Conversion of Lignocellulosic Biomass into Platform." Chemsuschem, vol 7, Issue 10, pp. 2774-2787, 2014.

[27]. Zhang, M. F., Qin, Y. H., Ma, J. Y., Yang, L., Wu, Z. K., Wang, T. L., Wang, W. G., Wang, C. W. "Depolymerization of Microcrystalline Cellulose by
The Combination of Ultrasound and Fenton Reagent." Ultrasonics Sonochemistry, vol. 31, pp. 404-408, 2016.

[28] C. Soundarrajan, S. J. Vennison, K. Saraswathi and Emmanuel, E. S. C. "Does Chip Size of Lignocellulose Bagasse Influence Lignin Degradation with $\mathrm{NaOH}$ Treatment. "Biosciences Biotechnology Research Asia, 2015 vol. 8, Issue 2, pp. 765-769, 2011. 